\title{
Kim był książę „Pomorza”, którego pokonał węgierski książę Béla?
}

W historiografii dotykającej kwestii obecności wygnanych książąt węgierskich w Polsce oraz ich uczestnictwa w walkach z Pomorzanami, głównie za ustaleniami genealogicznymi Oswalda Balzera ${ }^{1}$, przyjęło się uznawać, że wypadki te zaszły - wbrew literze węgierskich kronik - nie pod koniec rządów Mieszka II (1032-1034), a dopiero po powrocie Kazimierza Odnowiciela z wygnania (lata 40. XI wieku). Chronologię taką odnaleźć można zarówno w poświęconych mu biografiach ${ }^{2}$, jak i w pracach zajmujących się historią Pomorza $^{3}$, mimo iż opiera się ona na nader wątłych przesłankach. Informacje ze źródeł węgierskich konfrontuje się mianowicie z przekazem Anonima tzw. Galla, który wspomina o walkach Kazimierza z Pomorzem, milcząc jednocześnie o takim konflikcie za czasów Mieszka II. Dodatkowym wsparciem dla korekty węgierskich kronik jest przekonanie, że w ostatnich latach rządów Mieszko II nie miałby czasu ani dostatecznych sił na prowadzenie kampanii pomorskiej. Ponieważ problem datacji wydarzeń jest istotny dla genealogii piastowskiej — ustalenia daty zawarcia małżeństwa nieznanej z imienia Mieszkówny z księciem Bélą — poświęcili mu uwagę także Kazimierz Jasiński ${ }^{4}$ oraz Jan

1 O. BAlzer: Genealogia Piastów. Kraków 1895, s. 90-92.

2 S. Kętrzyński: Kazimierz Odnowiciel 1034-1058. W: TenżE: Polska X-XI wieku. Warszawa 1961, s. 466; K. DróżDż: Kazimierz Odnowiciel. Polska w okresie upadku i odbudowy. Wodzisław Śląski 2009, s. 100-104.

${ }_{3}^{3}$ B. ŚLIwiński: Pomorze w polityce i strukturze państwa wczesnopiastowskiego (X-XII w.). Kw. Hist. 2000, T. 2 (107), s. 19.

${ }^{4}$ K. JAsiński: Rodowód pierwszych Piastów. Warszawa-Wrocław [1992], s. 147-151. 
Tęgowski ${ }^{5}$. Obaj badacze opowiedzieli się za ustaleniami Balzera, przy czym pierwszy wzmocnił je, dostrzegając obecność jakiegoś Węgra w Czechach jeszcze w $1042 \mathrm{roku}^{6}$, natomiast drugi podał ten akurat argument w wątpliwość, skoro bezimiennego krewnego św. Stefana trudno bezsprzecznie utożsamić z konkretną osobą. Problemowi oddzielne studium poświęcił Gerard $\operatorname{Labuda}^{7}$ — nie będąc w pełni przekonanym do negowania wiadomości źródeł węgierskich, ostatecznie opowiedział się za czasami Kazimierza Odnowiciela jako bardziej prawdopodobnymi dla stoczenia walk Węgrów z Pomorzanami. Przyjęcia wygnańców przez Mieszka II nie kwestionował tylko Jerzy Dowiat ${ }^{8}$, który w przekazie o pokonaniu księcia Pomorza dostrzegał zniekształcone wspomnienie o losach Bezpryma, mimo że ten zamordowany został przed powrotem Mieszka II do kraju, a zatem i przed ewentualnym goszczeniem przez niego węgierskich książąt.

Współcześni historycy węgierscy nie widzą na ogół powodów, by podawać w wątpliwość informacje zawarte w kronikach ${ }^{9}$. Może wynikać to stąd, że - w przeciwieństwie do prób lepszego oświetlenia okresu monarchii pierwszych Piastów — problem dokładnej chronologii poszczególnych etapów wygnania książąt nie jest dla dziejów państwa Arpadów tak znaczący. Wypadałoby jednak zadać pytanie: czy faktycznie istnieją powody, by korygować węgierskie przekazy — jedynie odnośnie do tożsamości polskiego księcia?

5 J. TęGowski: W sprawie okoliczności i datacji matzeństwa nieznanej z imienia Piastów$n y$ z księciem węgierskim Béla. W: Res gestae Meridionales et Orientales. Studia ad Memoriam Professoris Henrici Ruciński. Red. E. BAGiŃsKa. Białystok 2009, s. 179-187.

${ }^{6} \mathrm{Za}$ utożsamieniem na tej podstawie tajemniczego krewnego św. Stefana z którymś z książąt przyjętych w Polsce opowiedział się już wcześniej J. Bieniak: Państwo Miecława. Studium analityczne. Warszawa 2012 (wyd. 1 - 1963), s. 107-108, przyp. 30.

${ }^{7}$ G. LABUDA: Udziat książat węgierskich w walkach polsko-pomorskich za Mieszka II czy za Kazimierza Odnowiciela? W: Opuscula minora in memoriam Josepho Spors. Red. J. HaUZIŃSKI. Słupsk 1993, s. 65-76; G. LABUdA: Wegierscy książęta w Polsce za czasów Mieszka II czy Kazimierza Odnowiciela? W: TenżE: Mieszko II król Polski (1025-1034). Czasy przełomu $w$ dziejach państwa polskiego. Poznań 2008, s. 140-147.

8 J. Dowiat: Bela I węgierski w Polsce (1031/32-1048). Prz. Hist. 1965, T. 56, s. 1-23.

9 Gy. Kristó, F. Makк: Az Árpád-házi uralkodók. Budapest 1988 (także wydania następne), s. 71, 79-80; F. Макк: I. Béla. In: Korai magyar történeti lexikon (9-14. század). Szerk. Gy. Kristó, P. Engel, F. Makk. Budapest 1994, s. 90. Datacja opiera się również na ustaleniach J. Dowiata. Gy. KRIsTó (A magyarok és lengyelek kapcsolatai a 10.-12. században. „Történelmi Szemle” 2000, 1-2 (42), s. 12) wspomina o dostrzeżonej przez polskich historyków możliwości pomylenia Kazimierza z Mieszkiem II, jednak nie podważa przekazu kronik węgierskich. Dodatkowo wskazuje na Czechy jako miejsce, w którym wygnańcy mogli spotkać się z Mieszkiem więzionym przez Udalryka, a stamtąd razem przybyć do Polski. Także M. Font (I. András és Bölcs Jaroszlav. „Világtörténet” 2015, 4 (37), s. 608-609), próbując datować małżeństwo starszego brata Béli, Andrzeja, z ruską Anastazją, zgodnie z wymową źródeł przyjmuje przybycie braci do Polski pod koniec panowania Mieszka II, walki z Pomorzem i sam pojedynek uznaje zaś za wątpliwe. 
Podstawową kwestią pozostaje wiarygodność kronik węgierskich, które jako jedyne dostarczają bezpośrednich informacji na temat poruszanego zagadnienia. Jak wiadomo, są to źródła stosunkowo późne - Szymon z Kezy spisał swoją kronikę pod koniec wieku XIII, kolejne kroniki pochodzą dopiero z XIV stulecia. Wśród badaczy węgierskich panuje zgoda co do tego, że wszystkie one czerpią ze wspólnego praźródła — zaginionych Gesta Ungarorum; polemiki budzi natomiast dokładny czas spisania tychże, wahający się od panowania Andrzeja I (1046-1060) po Kolomana Uczonego (1095-1116). Gesta... były później kontynuowane, lecz jednocześnie wcześniejsze partie poddawano przeróbkom, aby ideologicznie wzmocnić prawa do tronu kolejnych panujących ${ }^{10}$. Z tego powodu narracja zachowanych kronik, szczególnie zaś Chronici Hungarici compositio saeculi XIV (Chronicon Budense, Chronicon Pictum), składa się z warstw spisanych w różnych czasach, a pochodzące z oryginalnych Gesta... informacje ulec mogły modyfikacji. Historiografia węgierska zajmuje się przede wszystkim problemem datacji powstania konkretnych fragmentów na podstawie m.in. leksyki oraz odzwierciedlenia realiów opisywanych czasów, dzięki czemu określić można przydatność przekazu dla rekonstrukcji wydarzeń. Fragmentem dotyczącym pojedynku Béli z księciem Pomorza zajął się Dániel Bagi ${ }^{11}$.

W przeciwieństwie do lakonicznego, wręcz rocznikarskiego, przekazu Szymona z Kezy: „Andreas, Bela et Luenta de Boemia in Poloniam transeuntes a Misca Polonorum duce amicabiliter sunt recepti; ubi Bela Pomoramiae (sic!) ducem duello devincens, filia Miskae sibi datur in uxorem"12 — treść kronik z XIV wieku jest znacznie bardziej rozbudowana: wskazuje przyczynę konfliktu z Pomorzem, jaką miało być niepłacenie Polsce trybutu, a także szczegółowo opisuje przebieg pojedynku, do którego Béla zgłosił się z powodu tchórzostwa polskiego księcia i jego synów ${ }^{13}$. Analiza stylistyczna i leksykal-

${ }^{10}$ Zagadnienie przedstawiają np. Gy. KRISTó: A történeti irodalom Magyarországon a kezdetektöl 1241-ig. Budapest 1994. W języku polskim kwestię przybliżają m.in. R. GrzesIK: Kronika węgiersko-polska. Z dziejów polsko-węgierskich kontaktów kulturalnych w średniowieczu. Poznań 1999, s. 54-55 oraz D. BAGI: Królowie węgierscy w Kronice Galla Anonima. Kraków 2008, s. 33-37.

${ }^{11}$ D. BaGI: „Quamvis sim nobilior quam paganus ille, tamen pugnabo pro regni vestri commodo et honore domini ducis." Zur Kritik eines Kapitels der Ungarischen Chronikkomposition. W: Historia Narrat. Studia mediewistyczne ofiarowane Profesorowi Jackowi Banaszkiewiczowi. Red. A. PleszczyŃSKI. Lublin 2012, s. 97-110.

12 Simonis de Keza Gesta Hungarorum. Ed. A. Domanovszky. In: Scriptores Rerum Hungaricarum. Vol. 1. Budapest 1937, s. 177.

${ }^{13}$ Chronici Hungarici compositio saeculi XIV. Ed. A. Domanovszky. In: Scriptores Rerum Hungaricarum..., s. 334-335: „Endre, Bela et Leuente, qui fugerant in Bohemiam, inde propter paupertatis necessitudinem inopiam transierunt in Poloniam et a Misca duce Polonie benigne sunt suscepti et honorati. Tunc vero Pomorani annuas pensiones duci Polonorum, cui tenebantur, reddere recusarunt. Dux vero censum sibi debitum a Pomoranis armata manu cepit exigere. Pomoranis itaque paganis et Polonis Christianis comuniter placuit, ut duces eorum 
na tekstu wskazuje na XIII wiek jako najwcześniejszy czas jego powstania, sam opis pojedynku również odpowiada realiom późniejszym niż połowa wieku XI, został więc zapewne ubarwiony w ramach rozwoju kultury dworskiej ${ }^{14}$. Niezwykle cenne jest spostrzeżenie odnośnie do ukazanej przez kronikarza sytuacji rodzinnej księcia Mieszka ${ }^{15}$ : informacja o synach nie pasuje ani do Mieszka II, którego jedynym synem był Kazimierz, ani do Kazimierza, którego synowie byliby zbyt mali, aby brać udział w wyprawie wojennej przed powrotem Béli na Węgry (ok. 1048 roku — najstarszy Bolesław Szczodry miałby ok. 7 lat). Bagi dostrzega tu potencjalne odbicie sytuacji z czasów Władysława Hermana: z Pomorzanami walczył zarówno on, jak i jego synowie Zbigniew oraz Bolesław Krzywousty. Także kwestię płacenia jakiejś formy trybutu przez Pomorzan przypisać da się dopiero przełomowi XI/XII wieku. Można by zatem zaryzykować stwierdzenie, że tropy te wskazują na czas stworzenia wersji pierwotnej, którą wpleciono w czternastowieczną narrację ubarwioną dodatkowo wpływem kultury dworskiej. Aktualne na przełomie XI/XII wieku problemy pomorskie przypisano anachronicznie do czasów Béli, aby wyróżnić jego zasługi. Należy mieć bowiem na względzie fakt, że został protoplastą zwycięskiej gałęzi Arpadów, która za spisanie kronik odpowiadała ${ }^{16}$. W skraj-

duello confligerent et si caderet devictus Pomoranus, consuetam persolveret pensionem; si vero Polonus, tantummodo dampna fleret. Cum igitur tam Misca dux et filii eius horrerent duellum assumere inpositum, Bela seipsum per verbum interpretis in medium introducens sic dicebat: »Si vobis Polonis et domino duci placet, quamvis sim nobilior quam paganus ille, tamen pugnabo pro regni vostri conmodo et honore domini ducis«. Placuit itaque tam Pomorano quam Polonis. Cumque armati cum lancea se vinxissent (sic!), tam viriliter Pomoranum fertur Bela de suo dextrario detrusisse, ut de loco suo se movere non potuit, et gladio perfossum prostravit. Confessusque est ipse dux Pomoranus se culpabilem. Quo viso Pomorani duci Polonie humiliter subditi solitum tributum sine contradictione persolverunt. Dux vero inde revertens cum victoria per Belam aquisita, audaciam et potentiam valoris in Bela duce collaudans cum toto censu Pomoranico ei tradidit filiam suam in uxorem et universa que sibi necessaria fuerant sufficienter et copiose minstrari precepit, et eum in omnibus honoratum in ducato suo tenuit ac bona quantitate de terra eundem non omisit".

${ }^{14}$ D. Bagr: „Quamvis...”..., s. 99-100.

15 Tamże, s. 107-108.

16 Opis krótkiego, zaledwie trzyletniego, panowania Béli jest przy tym niezwykle korzystny i wyróżnia się na tle pozostałych władców, na co zwracał uwagę już B. Hóman: A szent László-kori Gesta Ungarorum és XII-XIII. századi leszármazói. Budapest 1925, wydanie elektroniczne: http://mek.niif.hu/07100/07139/html/0008/0010-33a.html: „Kto chciałby poznać węgierską historię z tego dzieła [kroniki Szymona z Kezy] czy też jego XIV-XV-wiecznych kontynuacji - kroniki budzińskiej, obrazkowej lub innych — z pewnością zakończyłby lekturę z odczuciem, że najwybitniejszymi przedstawicielami, najznaczniejszymi władcami z dynastii Arpadów byli Béla I i Władysław Święty. Przy nich usuwają się w cień nie tylko - wspomniany w zwięzłej części kroniki - Koloman [Uczony], Béla III i Béla IV, ale sam założyciel chrześcijańskiego Królestwa Węgier. O ile za uzasadnione uznajemy wyróżnienie zasług Władysława Świętego przez późniejszego pisarza, o tyle w żadnym wypadku nie można pojąć znaczącego pominięcia św. Stefana na korzyść Béli I. Choćby i Béla był wybitną osobowością, 
nej wersji założyć można by wręcz, że na potrzeby ukazania chwały założyciela linii pojedynek został po prostu wykreowany, a w rzeczywistości nic podobnego się nie wydarzyło ${ }^{17}$.

W tym kontekście warto pochylić się nad źródłem uznawanym za bałamutne i nieprzydatne dla ustalania chronologii wydarzeń, mianowicie nad Kronika węgiersko-polską ${ }^{18}$. Rzeczywiście nie pomoże ona w datacji tych konkretnie zdarzeń, ponieważ po prostu o nich milczy. Chociaż przedstawia nieco zniekształcony obraz relacji węgiersko-polskich z wieku XI, brakuje w niej motywu pojedynku. Jest to sytuacja zastanawiająca, jako że - co przekonująco wykazał Ryszard Grzesik ${ }^{19}$ — kronika bazuje na przekazach pisanych oraz ustnych dworu węgierskiego z pierwszych dziesięcioleci XIII wieku. Dlaczego zatem narracja podporządkowana ukazaniu uświęconej przyjaźni węgiersko-polskiej nie wspomina o zasługach Béli oraz o jego małżeństwie z Mieszkówną? Kronika opisuje losy wygnańców, wśród nich Béli, przyjętych w Polsce przez 18-letniego księcia Bolesława oraz jego matkę, regentkę-wdowę Dąbrówkę ${ }^{20}$. Stan ten w części odpowiada wydarzeniom znanym z innych źródeł. „Drugą turę” wygnańców węgierskich - trzech synów Béli i Mieszkówny przyjęli Bolesław Szczodry oraz Dobroniega-Maria w roku 1063, a być może także ok. roku 1059/1060. Parokrotne goszczenie różnych pokoleń wygnańców mogło z perspektywy czasu zlać się w Kronice... w jedno, trwające lat 16. Dziwi jednak brak pojedynku oraz tak istotnego dla relacji między dynastiami małżeństwa, z jakiego pochodził m.in. Władysław Święty, na opisie rządów którego w dodatku Kronika... się kończy. Czy tak znaczące pominięcie może przemawiać za tym, że jeszcze w czasie spisywania kroniki tradycja taka nie istniała, a wykreowana została dopiero później, aby trafić do przekazów Szymona z Kezy i kronik z XIV wieku? Godne odnotowania jest również to, że sam motyw pojedynku stoczonego przez przybysza z zewnątrz, dzięki czemu wygrywa on posiadłości lub żonę z lepszego rodu, występuje bardzo często w legendach założycielskich dynastii z zachodniej Europy, m.in. panów na Amboise czy hrabiów Andegaweniii ${ }^{21}$. Stamtąd mógł przywędrować na Węgry

w czasie krótkich trzech lat panowania nie mógłby dokonać tylu wielkich czynów, aby skłonić późniejsze generacje do takiego wychwalania”. Jeśli nie zaznaczono inaczej, tłumaczenia cytatów obcojęzycznych są mojego autorstwa.

${ }^{17}$ D. BAGi (,QQuamvis...”..., s. 100) wskazuje na taką tendencję do postrzegania opowieści o pojedynku, obecną m.in. w najnowszym węgierskim wydaniu kronik.

${ }_{18} \dot{Z} y w o t$ św. Stefana króla Węgier czyli Kronika węgiersko-polska. Tłum. i oprac. R. GRZESIK. Warszawa 2003.

19 R. GRZESIK: Kronika węgiersko-polska..., s. 208-212.

${ }^{20} \dot{Z} y w o t$ św. Stefana..., s. 96 i nast.

${ }^{21}$ G. Duby: Damy XII wieku. Tłum. A. i K. CholŃscy. Warszawa 2000, s. 196 i nast., szczególnie s. 201-203. Bohater-założyciel dynastii andegaweńskiej Enjeuger pokonuje w pojedynku sądowym (!) obrońcę oskarżycieli swojej matki chrzestnej, dzięki czemu uzyskuje cały jej majątek. Z kolei protoplasta panów na Amboise służył u hrabiego Andegawenii Fulka, 
i zainspirować do fabularnego ubarwienia początków panującej linii Arpadów. Założenie takie czyniłoby oczywiście przekaz o walkach z Pomorzanami całkiem bezwartościowym dla rekonstrukcji wydarzeń rozgrywających się w Polsce w 1 . poł. XI wieku.

Wydaje się, że to jednak podejście zbyt krytyczne. Wypada przychylić się do opinii Grzesika, że przekaz o pojedynku Béli w Polsce powstał stosunkowo niedługo po jego powrocie na Węgry, kiedy mógł dodatkowo pełnić ideologiczną funkcję w walce o tron z Andrzejem I i jego synem Salomonem. Gdyby atrakcyjny fabularnie motyw pojedynku trafił do tekstu kronik dopiero w XIII wieku, połączony zostałby raczej z Władysławem Świętym ${ }^{22}$. Należy przy tym podkreślić, że narracja kronik z XIV wieku została rozbudowana o anachroniczne szczegóły, lecz w najważniejszych punktach zgodna jest z wcześniejszą, krótką relacją Szymona, przekazującą podstawowe fakty bez ozdobników. To ich analizie trzeba zatem poświęcić uwagę, ponieważ stanowić powinny najdawniejszy rdzeń opowieści, wokół którego można było ją ubarwiać. Fakty te sprowadzić można do następującej sekwencji wydarzeń: (1) wygnańców przyjął Mieszko, (2) Béla pokonał księcia Pomorza, (3) za co otrzymał córkę Mieszka za żonę. Od razu staje się widoczne, że w polskiej historiografii kwestionuje się jedynie zdarzenie (1), zaś (2) i (3) przyjmuje się za wiarygodne. Tymczasem sprawa nie jest tak oczywista właśnie w przypadku informacji o Pomorzu, która stanowi podstawę częściowej korekty węgierskiego przekazu.

Problem staje się doskonale widoczny w toku dalszej narracji kronikarskiej, opisującej losy braci Béli, którzy opuściwszy Polskę, aby nie korzystać z jego uprzywilejowanej pozycji, udali się na Ruś, a stamtąd trafili do Kumanów (Połowców): „Quod Andreas et Luenta aegre ferentes, ne ipsius [Bela] nomine viverent in Polonia, in Rutheniam transierunt. Et dum ibi a duce Lodomeriae (propter Petrum regem) suscepti non fuissent, ad terram vadunt deinde Comanorum"23. Działo się to przed rokiem 1046, kiedy powrócili na Węgry. W tym czasie nie daje się jeszcze dostrzec aktywności Kumanów przy granicach Rusi - przypada ona bowiem na późniejsze dziesięciolecia. Powieść minionych lat po raz pierwszy wspomina o Połowcach pod rokiem 1054/1055 $5^{24}$,

który ożenił go z posiadającą ziemie Amboise dziewczyną, aby zatrzymać go przy boku swoim i syna.

22 R. Grzesik: Polska Piastów i Węgry Arpadów we wzajemnej opinii (do 1320 roku). Warszawa 2003, s. 52.

${ }^{23}$ Simonis de Keza..., s. 177. W relacji Chronici Hungarici compositio saeculi XIV..., s. 336: „Displicuit autem Endre et Leuente, quod per Belam apud ducem Polonie quasi appendices degerent, dedignatique sunt occasione sui nominis in ducis curia permanere. Et accepta a duce licentia, Bela fratre suo ibidem relicto euntes iverunt ad regem Lodomerie, qui ipsos non recepit. Cumque non haberent, ubi caput suum reclinarent, abinde ad Cumanos perrexerunt".

${ }^{24}$ Powieść minionych lat. Tłum. i oprac. F. Sielicki. Wodzisław Śląski 2014, s. 133, r. 6562 [1054]: „Tegoż lata przychodził Bołusz z Połowcami i zawarł Wsiewołod pokój z nimi, i powrócili Połowcy, skąd przyszli”. 
następnie o ich ataku na Ruś w roku $1061^{25}$. Nie można oczywiście całkiem wykluczyć, że Węgrzy faktycznie dotarli do Kumanów, którzy ok. połowy XI wieku pojawili się na zachód od Wołgi i zajęli stepy nadczarnomorskie ${ }^{26}$. Historycy węgierscy dostrzegli jednak ten problem i wystąpienie nazwy Kumanów w narracji uznali za ewidentny anachronizm; pod tym mianem kryją się najpewniej Pieczyngowie ${ }^{27}$. Według Márty Font początek pobytu braci Béli na Rusi wypada datować na lata 1034-1036, w okresie konfliktów z Pieczyngami, kiedy wspierać mogli Jarosława Mądrego ${ }^{28}$. Sama kwestia obecności nazwy Kumanów w tekście kronik węgierskich rzucić może zaś światło na czas spisania interesującego nas fragmentu. Jednym z najbardziej znanych epizodów z ich udziałem jest pokonanie kumańskiego wojownika przez Władysława Świętego ${ }^{29}$, syna Béli, podczas najazdu w 1068 roku. Chociaż wydarzenie to zostało spopularyzowane $w$ ramach kultu świętego króla-rycerza ratującego porwane dziewice przed poganami ${ }^{30}$, to także $\mathrm{i} \mathrm{w}$ tym wypadku

25 Tamże, s. 134, r. 6569 [1061]: „Przyszli Połowcy po raz pierwszy na ziemię ruską wojować”. Zob. też C.A. Плетнёва: Полови̧ы. Москва 1990, s. 41.

${ }^{26}$ С.А. Плетнёва: Половиы..., s. 35, 40-42; Sz. KovÁcs: A kunok története a mongol hódításig. Szeged 2012, s. 43 (dysertacja doktorska); С. Темушев: География и динамика половеиких набегов на Русь (вторая половина XI-начало XIII века). In: Rus' and the World of the Nomads (the Second Half of the $9^{\text {th }}-16^{\text {th }} \mathrm{c}$.). Publication from the $7^{\text {th }}$ International Scientific Conference, Plzeñ, 23 $3^{\text {th }}-26^{\text {th }}$ November 2016. Ed. V. NaGiRnYy. Krakow 2017 (Colloquia Russica, Series I, Vol. 7), s. 126-127.

${ }^{27}$ Gy. Kristó, F. Makк: Az Árpád-házi uralkodók..., s. 71. Tendencję do nazywania Kumanami także innych ludów stepowych dostrzegł u Anonima, autora trzynastowiecznych Gesta Hungarorum, B. Hóman: A szent László-kori.... „Ciekawe, że Anonim żyjący w końcu XII wieku odpowiednio dla ówczesnych stosunków pomija już wspominanie Pieczyngów i rozróżnienie Białych oraz Czarnych Kumanów, sojuszników księcia kijowskiego nazywając po prostu Kumanami”.

${ }_{28}^{28}$ M. Font: I. András és Bölcs Jaroszlav..., s. 614.

${ }^{29}$ Chronici Hungarici compositio saeculi XIV..., s. 368-369: „Vidit denique Beatissimus Ladizlaus dux unum paganorum, qui super dorsum equi sui ducebat unam puellam Hungaram speciosam. Sanctus ergo dux Ladizlaus putans illam esse filiam episcopi Waradiensis et quamvis esset graviter vulneratus, tamen illum celerrime persecutus est super equum illum, quem Zug nominabat. Cum autem attingeret ut eum lancearet, minime poterat, quia nec equus eius celerius currebat, nec equues illius aliquantulum remanebat, sed quasi brachium hominis erat inter lanceam et dorsum Cuni. Clamavit itaque sanctus dux Ladizlaus ad puellam et dixit: »Soror speciosa, accipe Cunum in cingulo et iacta te in terram«. Quod et fecit. Cumque Beatus Ladizlaus dux procul illum lanceasset in terra iacentem, voluit eum interficere. Quem puella valde rogavit, ne eum interficeret, sed ut dimitteret. Unde in hoc notatur, quod fides in mulieribus non sit, quia forte amore stupri illum liberare voluit. Sanctus autem dux diu cum eo luctando et absisco nervo illum interfecit".

${ }^{30} \mathrm{Na}$ temat tego aspektu kultu G. Klaniczay: A Szent László-kultusz kialakulása. In: Tenże, L. Koszta, T. Körmendi: Nagyvárad és Bihar a korai középkorban. Tanulmányok Biharország történetéröl. Nagyvárad 2014, s. 31-39. Ostatnio o motywie w kazaniach barokowych: S.N. MedGyesY: Szent László király alakja a magyarországi barokk irodalomban. In: Szent király, lovagkirály. A Szent László-herma és a koponyaereklye vizsgálatai. Szerk. L.A. KRIStóF, Z. LuKÁCSI, L. PATONAY. Győr 2017, s. 64. 
zagrożenie pochodziło nie od Kumanów, a od Pieczyngów ${ }^{31}$. Szilvia Kovács uznaje, że pierwsze rzeczywiste zetknięcie się Węgrów z Kumanami nastąpiło w roku 1091, kiedy Władysław Święty dwukrotnie odparł ich ataki ${ }^{32}$. Oznaczałoby to, że nazwa Kumanów trafić mogła do narracji dopiero po tej dacie, a zatem fragment opisujący dzieje Béli i jego braci powinien zostać spisany najwcześniej w ostatnich latach panowania Władysława (1077-1095) lub już w czasach Kolomana Uczonego. Za tą drugą możliwością opowiada się Font, dostrzegając we wspomnieniu w narracji księcia Włodzimierza (dux Lodomeriae) odbicie stosunków współczesnych Kolomanowi ${ }^{33}$. Podobnie jak w przypadku Kumanów jest to rzeczywistość nieadekwatna dla lat 30. lub 40. XI wieku. Powstanie ośrodka dzielnicowego z siedzibą we Włodzimierzu datować można dopiero po śmierci Jarosława Mądrego (1054) ${ }^{34}$.

Umieszczenie w narracji wyraźnie anachronicznych realiów politycznych stawiać powinno pod ogromnym znakiem zapytania Pomorzan jako rzeczywistych przeciwników polskiego księcia. Nietrudno sobie wszak wyobrazić, że zlecający spisanie kronik syn lub wnuk Béli wiedział o walecznych czynach przodka w Polsce, ale tożsamość przeciwnika uległa zapomnieniu i ukazana została zgodnie z sytuacją polityczną współczesną potomkom, podobnie jak wspomniane wcześniej kwestie: Kumanów oraz księcia Włodzimierza. Tymczasem potencjalnych przeciwników zarówno dla Mieszka II, jak i Kazimierza Odnowiciela nie brakuje: tajemniczym księciem „Pomorza” mógłby być nawet związany z Mazowszem Miecław, a wśród wymienianych przez Galla reges et duces oraz finitimae gentes najeżdżających Polskę ${ }^{35}$ znaleźć by się mogli Prusowie albo Lucice. Przyjmowanie zatem dotyczącej Pomorza wiadomości węgierskich kronik za wiarygodną — w przeciwieństwie do informacji o tożsamości księcia polskiego - wydaje się pochopne i ryzykowne. Anachroniczne mogą być bowiem obie.

Nie jest ponadto możliwe wykazanie, kiedy rozpoczął się konflikt polsko-pomorski. To, że Gall pisze wprost o walkach z Pomorzanami po powrocie Odnowiciela z wygnania, nie oznacza, że nie zdarzyły się one wcześniej. Milczenie źródeł, zwłaszcza odległych od opisywanych wydarzeń, nie może świad-

${ }^{31}$ Gy. GYőRfFY (A „lovagszent” uralkodása (1077-1095). „Történelmi Szemle” 1977, 3-4 (20), s. 536) uznaje, że Kumanowie (wraz z Pieczyngami) pierwszy raz w granicach Węgier pojawili się w 1078 r. Zob. też G. Klaniczay: A Szent László-kultusz..., s. 31.

32 Sz. Kovács: A kunok története..., s. 245-252.

${ }^{33}$ M. Font: I. András és Bölcs Jaroszlav..., s. 609-610.

${ }^{34}$ Powieść minionych lat... (s. 133) po raz pierwszy wymienia wtedy Włodzimierz jako osobny ośrodek władzy, jednak o realnym istnieniu odrębnego księstwa włodzimierskiego mówić można w późniejszych dziesięcioleciach (lata 70. XI w.).

${ }^{35}$ Galli Anonymi Cronicae et gesta ducum sive principum Polonorum. Ed. K. MaleczyŃSKI. W: MPHn, T. 2, s. 42: ,,reges et duces in circuitu Poloniam quisque de parte sua conculcabat”; s. 44: „totam Poloniam a Pomoranis et Bohemicis aliisque finitimis gentibus occupatam liberavit". 
czyć o nieistnieniu zjawiska. Przekonanie Balzera, że gdyby walki z Pomorzem rozegrały się za Mieszka II, to zachowałaby się o nich wzmianka w innym źródle ${ }^{36}$, jest nadzwyczaj życzeniowe wobec wątłości przekazów źródłowych dla tego okresu. Nie wiadomo, kiedy dokładnie Pomorze uniezależniło się od państwa Piastów - czy stało się to już za panowania Chrobrego, czy dopiero w czasie tzw. kryzysu monarchii. Co więcej, nie wiemy także, czy Pomorze stanowiło wówczas organizm jednolity, dwa osobne organizmy, a może kilka tworów plemiennych ${ }^{37}$. Wszystkie te niewiadome nie wykluczają możliwości wystąpienia konfliktu pod koniec rządów Mieszka II, o ile faktycznie był to konflikt z Pomorzem.

Należy przyjrzeć się również temu, w jaki sposób Gall przedstawia kwestię pomorską $\mathrm{w}$ całości narracji. Otóż podejmowanie wypraw na Pomorze oraz chęć włączenia go w granice państwa polskiego stanowią jedną z głównych aktywności Bolesława Krzywoustego, którego waleczne czyny opiewa kronika. Obecność antagonizmu polsko-pomorskiego sygnalizowana jest wobec tego już w rozbudowanej partii o rządach Bolesława Chrobrego ${ }^{38}$, aby przewijać się przez opisy panowania wszystkich kolejnych Piastów, z których dopiero Krzywousty wykazał się pełną skutecznością. Chociaż Mieszkowi II poświęcił Gall tylko sześć zdań, jedynie ogólnie wspominając o licznych czynach wojskowych, to i w nich - wbrew opinii Balzera - pośrednio widoczna jest ciągłość konfliktu z Pomorzem: Mieszko „vicinis omnibus extitit odiosus” ${ }^{39}$ — zatem znienawidzony mógł być też przez Pomorzan, których podbić miał jego ojciec. Wobec fragmentarycznej wiedzy Galla na temat tak odległych mu czasów, mylenia m.in. informacji genealogicznych (np. filiacja Rychezy, wiek Mieszka II i Kazimierza Odnowiciela), milczenia o znanych nam z innych źródeł wydarzeniach i osobach (np. Bezprym i Otto, bracia Mieszka II), a także niepewności co do poprawnej chronologii opisywanych epizodów - tym bardziej nie można polegać na jego informacjach tak bezkrytycznie, by łączyć je z innymi o wątpliwej wiarygodności, w dodatku przy wynikającej z tego konieczności korekty części drugiego przekazu.

Jak zatem jawi się anachroniczność przekazu węgierskiego odnośnie do tożsamości księcia Polaków? Jeśli uznamy za słuszne datowanie spisania tego fragmentu na przełom XI/XII wieku, nie mamy do czynienia z przeniesieniem funkcjonującego wówczas imienia książęcego na czasy dawne - co przemawiać może za użyciem imienia zapamiętanego i odpowiadającego prawdzie.

\footnotetext{
${ }^{36}$ O. Balzer: Genealogia Piastów..., s. 91.

37 Kwestie te omawia J.M. PISKorski: Pomorze plemienne. Historia - archeologia językoznawstwo. Wodzisław Śląski 2014, s. 30-99.

${ }_{38}$ Galli Anonymi..., s. 17: „Ipse namque Selenciam, Pomoraniam et Prusiam usque adeo vel in perfidia persistentes contrivit, vel conversas in fide solidavit, quod ecclesias ibi multas et episcopos per apostolicorum, ymmo apostolicus per eum ordinavit".

39 Tamże, s. 40.
} 
Należy się bowiem zastanowić, w jaki sposób właśnie imię Mieszka trafić mogło do tekstu kroniki, gdyby znaleźć się w nim miało z powodu pomyłki. Przemysław Wiszewski, przyjmując za większością badaczy, że wygnanych książąt przyjął Kazimierz Odnowiciel, podobnie jak Tadeusz Grudziński wskazał, że możliwą przyczyną błędu stało się utrwalenie filiacji Piastówny w tradycji węgierskiej. Mieszko mógł zostać upamiętniony w zapisce nekrologowej córki, skąd trafiłby do kroniki jako potencjalny książę goszczący wygnańców ${ }^{40}$. Wydaje się jednak, że jest to tworzenie następnej zbędnej, piętrowej hipotezy. Mieszko II należał do przodków zwycięskiej linii Arpadów i w perspektywie ok. trzech pokoleń był pamiętany po prostu w ten sposób. Najmłodszy z synów Béli i Mieszkówny otrzymał imię Lambert, najprawdopodobniej właśnie po dziadku — Mieszku II Lambercie. Sama pamięć o przodku nie jest jednak dostatecznym umotywowaniem przypisania mu faktu ugoszczenia wygnańców. Warto spojrzeć na zagadnienie z innej strony, świadczącej o małym prawdopodobieństwie wystąpienia tego rodzaju pomyłki. Otóż, jeśli osobą zlecającą spisanie kronik byłby Władysław Święty, wnuk Mieszka II, nie mógłby on dostarczyć kronikarzowi informacji błędnej. Wiadomo, że Władysław urodził się w Polsce i przynajmniej kilka lat wychowywał się na polskim dworze ${ }^{41}$ poznał zatem osobiście wuja, Kazimierza Odnowiciela. Gdyby to Kazimierz udzielił pomocy Béli, jego syn musiałby być tego świadomy; także przy założeniu, że wuja znał jedynie z opowieści, trudno uznać, by w dobie wielkiego znaczenia więzi rodzinnych nie miał wiedzy na temat najbliższych krewnych oraz wydarzeń, które rozegrały się w Polsce i poskutkowały zadzierzgnięciem więzów rodzinnych. Podobną świadomość zagadnienia założyć można w przypadku drugiego potencjalnego zleceniodawcy spisania przekazów prawnuka Mieszka II, Kolomana Uczonego. Ojcem Kolomana był starszy brat Władysława, pierworodny syn Béli i Mieszkówny, Géza - z racji starszeństwa lepiej jeszcze pamiętać musiał Kazimierza, a pamięć tę przekazać powinien synowi ${ }^{42}$. Nie można nawet wykluczyć, że informatorem był wspomniany

40 P. Wiszewski: Domus Bolezlai. W poszukiwaniu tradycji dynastycznej Piastów (do okoto 1138 roku). Wrocław 2008, s. 538-540.

${ }^{41}$ Galli Anonymi..., s. 52: „Wladislauus ab infancia nutritus in Polonia fuerat, et quasi moribus et vita Polonus factus fuerat". Podobnie Chronici Hungarici compositio saeculi XIV..., s. 335: „Bela vero dux ipse in Polonia duos genuit filios, quorum unus Geysa, alter autem Ladizlaus nomine avi sui est vocatus". Prawdopodobnie wiadomości Galla oparte są na informacjach pozyskanych przez niego podczas pobytu na Węgrzech, czy to z Gesta Ungarorum, czy to $\mathrm{z}$ opowieści ustnych; nie można także wykluczyć, że Władysława znał osobiście. W świetle przekazu węgierskiego mógł się on urodzić w latach 30. XI w., a zatem opuszczając Polskę, byłby nawet nastolatkiem.

${ }^{42}$ Nie jest znana dokładna data urodzenia Kolomana, w związku z czym nie sposób określić, w jakim był wieku, kiedy zmarł Géza (1077). Gy. Kristó, F. MaKK (Az Árpád-házi uralkodók..., s. 129) proponują ok. 1070 r., ale jest to dość swobodne przybliżenie; nie jest pewna ani tożsamość jego matki, ani datacja małżeństwa rodziców. Po śmierci ojca Koloman wraz 
Lambert, najmłodszy z braci, imiennik dziadka, ponieważ data jego śmierci nie jest pewna ${ }^{43}$. W dodatku wszyscy wspomniani trzej bracia przebywali w Polsce kilkakrotnie już po okresie dzieciństwa (ok. 1059/1060, 1063/1064, 1073/1074) ${ }^{44}$ i również z tego powodu orientowali się we wzajemnych stosunkach rodzinno-dynastycznych, a te bynajmniej nie uległy rozluźnieniu — nie tylko Władysław Święty przyjął wygnanego z Polski Bolesława Szczodrego z rodziną, ale i Koloman Uczony odbywał zjazdy z Bolesławem Krzywoustym, którego gościł ponadto przy okazji pielgrzymki pokutnej Piasta na Węgrzech. Nie wydaje się wobec tego prawdopodobne, aby władca węgierski odpowiedzialny za spisanie kronik dopuścił do pomylenia tożsamości polskiego księcia, ponieważ zarówno Mieszko II, jak i Kazimierz Odnowiciel byli na tyle istotnymi i bliskimi krewnymi, że podstawowe wiadomości na ich temat nie zdążyłyby się jeszcze zatrzeć w pamięci następnych pokoleń.

Wobec tego, co ustaliliśmy, należy pochylić się nad przyjętą i powielaną argumentacją Balzera o niemożności zorganizowania wyprawy pomorskiej (?) w ostatnich latach panowania Mieszka II. Brak byłoby na nią zarówno czasu, jak i sił u księcia „złamanego przeciwnościami”45. Jest to stwierdzenie niezwykle arbitralne, zakładające w dodatku konkretną postawę psychiczną, która przedstawiać mogła się wręcz odwrotnie: klęska motywować mogła do zdwojenia wysiłków, aby dawną świetność odzyskać. Jest to jednak przede wszystkim teza sprzeczna z dostępnym materiałem źródłowym.

O tym, że Mieszko II „,miles probus fuit, multaque gesta militaria perperavit" - informuje Gall ${ }^{46}$. Wiadomość może być pustą pochwałą lub dotyczyć czasu sprzed klęski roku 1031 — wiadomo m.in. o uczestnictwie Mieszka w wojnach Chrobrego z Henrykiem II oraz o jego wyprawie na Saksonię dysponujemy jednak wysoce wiarygodnym przekazem współczesnym, który nie pozwala dojrzeć w księciu człowieka niezdolnego do „podjęcia wyprawy przeciw Pomorzanom i to $\mathrm{z}$ pomyślnym wynikiem dla oręża polskiego" ${ }^{47}$.

z bratem znaleźli się pod opieką stryja, Władysława Świętego, zatem to również on dostarczałby informacji o przodkach i krewnych.

${ }^{43}$ M. Wertner (Az Árpádok családi története. Nagy-Becskerek 1892, s. 175-176) uznaje 1096 r. za prawdopodobną datę śmierci Lamberta. Z pewnością nie żył w 1102 r., kiedy jego księstwo przekazane zostało przez Kolomana Uczonego bratu, księciu Álmosowi. Gy. Kristó, F. MAKK (Az Árpád-házi uralkodók..., s. 126) uznają za rok śmierci 1095. Podobnie ok. 1095 r. podaje F. МАкк: Lampert. In: Korai magyar történeti lexikon..., s. 393.

${ }^{44} \mathrm{~W}$ tym ostatnim wypadku w Polsce przebywał sam Lambert, wysłany przez Gézę, aby szukać wsparcia przeciw rywalowi do tronu, Salomonowi - zob. Chronici Hungarici compositio saeculi XIV..., s. 380. O kolejnych pobytach węgierskich wygnańców w Polsce na podstawie źródeł węgierskich pisze zbiorczo Gy. Kristó: A magyarok és lengyelek kapcsolatai..., s. 13 oraz R. Grzesik: Polska Piastów i Wegry Arpadów..., s. 53.

45 O. BAlzer: Genealogia Piastów..., s. 91.

46 Galli Anonymi..., s. 40.

47 O. BAlzer: Genealogia Piastów..., s. 91. 
Roczniki hildesheimskie informują o podziale kraju na zjeździe w Merseburgu (1032), a zarazem także o tym, że przed śmiercią (maj 1034) Mieszko zdołał podział ten zlikwidować i władał Polską samodzielnie: ,,...] imperator clementius, quam ipse opinaretur, suscepit eique et eius patrueli, cuidam Thiedrico, regnum, quod ipse solus ante possederat, divisit; quod ipse tamen postea solus iterum sibi usurpavit’"48. Użyte w zapisce wyrażenie sibi usurpavit, na co zwrócił uwagę Labuda ${ }^{49}$, implikuje niezastosowanie się do cesarskich rozkazów poprzez działanie przemocą — bądź podstępem. Mamy zatem do czynienia z sytuacją, w której Mieszko w niespełna 2 lata, być może orężnie, odzyskał pełnię władzy. Rola jego młodszego brata Ottona w tym czasie nie jest jasna ${ }^{50}$ : jeśli również otrzymał własną dzielnicę, to już w 1033 roku zmarł i brak podstaw, aby uznać tę śmierć za nienaturalną. Nawet i wtedy jednak przeszkodę do zjednoczenia kraju stanowił Dytryk. Przytoczony tu wcześniej przekaz Roczników hildesheimskich wspomina zresztą tylko o nim i tylko jego ukazuje jako współrządcę Mieszka, który następnie w tajemniczych okolicznościach znika ze źródeł, prawdopodobnie z Polski wygnany. Należy więc zastanowić się, czy słuszne jest mnożenie wypraw militarnych, jakie miałby podjąć Mieszko II - czy poza zakończoną sukcesem rozprawą z Dytrykiem zaistnieć musiałaby odrębna akcja przeciw księciu Pomorza (?), o której mówią węgierskie kroniki. Mogą one przecież oświetlać właśnie sprawę Dytryka.

Pochodzenie Dytryka i jego pokrewieństwo z Piastami nie budzą wątpliwości ${ }^{51}$ — jako patruelis Mieszka II był jego bratem stryjecznym, wnukiem Mieszka I oraz Ody, córki margrabiego Dytryka, po którym otrzymał imię. Nie jest dla tych rozważań istotne, czyim konkretnie był synem ${ }^{52}$ - po wygnaniu Ody jej synowie zapewne wychowywali się w Saksonii, być może w Haldensleben. Ich sytuacja oraz prawa do dziedziczenia po Mieszku I nie były w Rzeszy kwestionowane, skoro cesarz Konrad postanowił nadać Dytrykowi dział w obrębie Polski. Nie wiadomo, którym obszarem Dytryk miałby wła-

${ }^{48}$ Annales Hildesheimenses. Ed. G. WaItz. In: Scriptores Rerum Germanicarum in usum scholarum. Hannover 1878, s. 37.

${ }^{49}$ G. Labuda: Mieszko II..., s. 101.

${ }^{50}$ Zwykle za przekazem Wipona przyjmuje się, że Otto wraz z Bezprymem wystąpił przeciw Mieszkowi II, a później otrzymał od cesarza swoją dzielnicę. Polemizowała z tym D. BoRAWSKA: Kryzys monarchii wczesnopiastowskiej w latach trzydziestych XI wieku. Warszawa 2013 (wyd. 1 - 1964), s. 68-72. W tę stronę poszedł również ostatnio J. Osıński $(Z$ dziejów Polski wczesnopiastowskiej. Genealogia, ustrój, podbój. Kraków 2018, s. 64-66, 69-71), kwestionując postrzeganie Ottona jako spiskowca i przeciwnika Mieszka II.

${ }^{51}$ O. BAlzer: Genealogia Piastów..., s. 57-58; K. JASIŃski: Rodowód..., s. 126-127.

${ }^{52}$ Ponieważ Dagome iudex nie wymienia Świętopełka obok Mieszka i Lamberta, zwykło się uznawać, że w chwili wystawienia dokumentu już nie żył, a zatem nie pozostawił po sobie potomstwa, zob. K. JAsiŃsKi: Rodowód..., s. 101-103. Zupełnie inaczej kwestię tę widzi E. Rymar (Rodowód książąt pomorskich. T. 1. Szczecin 1995, s. 68-70), to właśnie w Świętopełku upatrując ojca Dytryka. 
dać - Labuda zaproponował Wielkopolskę ${ }^{53}$, z kolei Edward Rymar wiązał go z Pomorzem, które miałoby stanowić obszar trybutarny Niemiec od czasów Mieszka I i na tej zasadzie zostałoby przyznane Dytrykowi ${ }^{54}$.

Wobec uzasadnionych wątpliwości odnośnie do uznania Pomorza za kraj pochodzenia przeciwnika Béli i Mieszka II nie byłaby to kwestia niezmiernie istotna, jednak niedawno na pewną możliwość w tym zakresie zwrócił uwagę Jacek Osiński. Według badacza roszczenia Dytryka do spadku po przodkach powinny opierać się na kształcie terytorialnym państwa Mieszka I. Kształt ten znamy z regestu Dagome iudex - chociaż w wielu aspektach jest on wciąż dyskusyjny, akurat w tym wypadku nie wzbudza większych zastrzeżeń: było to państwo, w granicach którego znajdowało się Pomorze. Wobec tego to właśnie te ziemie mógł uzyskać Dytryk jako dzielnicę — podstawą ku temu nie musiała być wcale hipotetyczna zależność trybutarna od Rzeszy ${ }^{55}$. W ten sposób stałby się księciem Pomorza. Zauważmy także, że Szymon z Kezy czyni w tym aspekcie rozróżnienie: przeciwnik Béli to dux Pomoraniae określony terytorialnie, natomiast Mieszko to dux Polonorum - określony etnicznie. Rymar, mimo że jak większość badaczy opowiadał się za datacją konfliktu na lata 40. XI wieku, sugerował, że księciem wspomnianym przez kroniki węgierskie mógł być właśnie Dytryk, wedle hipotezy badacza — brat pomorskiego Siemomysła, występującego w 1046 roku wraz z Kazimierzem Odnowicielem i czeskim Brzetysławem przed cesarzem Henrykiem III ${ }^{56}$. Są to oczywiście tylko poszlaki, trzeba mieć jednak na względzie, że poświadczać mogą stan faktyczny: związek Dytryka z Pomorzem. Kroniki węgierskie oświetlałyby wobec tego sytuację końca rządów Mieszka II, przechowawszy informację o terytorium podlegającym Dytrykowi w myśl postanowień zjazdu merseburskiego.

Na uwagę w tym kontekście zasługuje także sam pojedynek, który zgodnie z wymową kronik miałby stoczyć Béla ok. 1033 roku. Wipon, biograf cesarza Konrada II, uczestniczący w jego wyprawach wojennych ${ }^{57}$ i wobec tego dysponujący wiarygodnymi danymi o związanych z nimi obyczajach, dostarcza niezwykle ważnego dla tematu przekazu. O przebiegu walk sasko-lucickich, datowanych właśnie na rok 1033, pisze następująco:

Deinde collectis copiis de Saxonia super eos, qui Liutizi vocantur quique olim semichristiani, nunc per apostaticam nequitiam omnino sunt pagani, imperator venit

${ }_{53}$ G. LabUdA: Mieszko II..., s. 100.

${ }^{54}$ E. Rymar: Rodowód..., s. 48, 54, 74-80.

55 J. Osı́́ski: $Z$ dziejów..., s. 20-22, 30-34; tam też literatura na temat przynależności Pomorza do państwa Mieszka I - s. 21, przyp. 11.

56 E. RYMAR: Rodowód..., s. 74 i nast.

57 J. Sochacki: Wstęp. W: Wipon: Chwalebne czyny cesarza Konrada II. Tłum. E. MiLKamanowicz. Kraków 2005, s. XI. 
ibique conflictum implacabilem mirabiliter diremit. Inter Saxones enim et paganos fiebant ea tempestate multae dissensiones et incursiones. Cumque caesar veniret, coepit quaerere, ex qua parte pax, quae diu inviolata inter eos fuerat, prius corrumperetur. Dicebant pagani a Saxonibus pacem primitus confundi idque per duellum, si caesar praeciperet, probari. Econtra Saxones ad refellendos paganos similiter singulare certamen, quamvis iniuste contenderent, imperatori spondebant. Imperator consulentibus principibus suis, licet non satis caute ageret, hanc rem duello diiudicari inter eos permisit. Statim duo pugiles congressi sunt, uterque a suis electus. Christianus in sola fide, quae sine operibus iustitiae mortua est, confidens et non diligenter attendens, quod Deus, qui veritas est, omnia in vero iudicio disponit, qui solem suum oriri super bonos et malos facit, qui pluit super iustos et iniustos, audacter pugnare coepit. Paganus autem solam conscientiam veritatis, pro qua dimicabat, prae oculis habens acriter resistebat. Postremo christianus a pagano vulneratus cecidit. Ex qua re pagani in tantam elationem et audaciam venerunt, ut, nisi imperator adesset, continuo irruerent super christianos; sed imperator ad compescendas incursiones eorum construxit castrum Wirbinam, in quo praesidia militum locabat, et principes Saxoniae, ut unanimiter resisterent paganis, sacramento et imperiali iussione constringebat. Deinde reversus est in Franciam ${ }^{58}$.

Nie może zatem budzić żadnych wątpliwości fakt, że forma rozstrzygnięcia sporów poprzez pojedynek — „sąd boży” — do którego stawali reprezentanci stron, w latach 30. XI wieku funkcjonowała ${ }^{59} \mathrm{i}$ respektowana była przez samego cesarza, co spotkało się zresztą z lekką naganą Wipona. Zarówno zorientowany w obyczajach Rzeszy Mieszko II, jak i wychowany w Saksonii Dytryk mógł zaproponować takie rozwiązanie konfliktu. Przegrany pojedynek z Bélą - niekoniecznie osobisty, może przez reprezentanta - musiałby skutkować odstąpieniem od roszczeń i czasowym przynajmniej opuszczeniem Polski, a tym samym zniknięciem ze źródeł. Mieszko II przywłaszczyłby sobie w ten sposób ponownie władzę nad całością kraju - po części podstępem, po części przemocą - sprawcę swojego sukcesu zaś wynagrodził małżeństwem z córką.

Brak dostatecznych podstaw, aby kwestionować przekaz węgierskich kronik o przyjęciu wygnanych książąt przez Mieszka II, a za wiarygodne przyjmować ich walki z Pomorzanami. Istnieją zasadne powody, aby to właśnie informację o Pomorzu podać w wątpliwość jako anachronizm właściwy czasom spisania pierwotnej wersji Gesta Ungarorum. W przeciwieństwie do imienia polskiego księcia może odzwierciedlać ona późniejszą sytuację polityczną: walki z Pomorzem toczone przez Władysława Hermana i jego synów podob-

58 Wiponis opera. Ed. H. BresslaU. In: Scriptores Rerum Germanicarum in usum scholarum. Hannover-Leipzig 1915, s. 52-53.

${ }^{59}$ Zwracał na to uwagę G. LABudA (Udział..., s. 71), odnosząc jednak ten przykład do potencjalnych wydarzeń z czasów Kazimierza Odnowiciela. 
nie jak występujący w narracji Kumanowie odpowiadają wcześniejszym Pieczyngom, a książę Włodzimierza (dux Lodomeriae) księciu całej Rusi. Łączenie informacji o Pomorzu z równie niepewnym przekazem Galla, który nie wyklucza konfliktu pomorskiego za panowania Mieszka II, i na tej zasadzie przesuwanie zaszłych wydarzeń w czasy Kazimierza Odnowiciela jest dodatkowo nieuzasadnione. Wiadomo, że Mieszko II w latach 1032-1034 rozprawił się z krewnym dysponującym własną dzielnicą i zapanował nad całością kraju, ale nie wiadomo, w jaki sposób tego dokonał. Kroniki węgierskie mogą być do tych wiadomości komplementarne: mogą ukazywać, że sukces nastąpił dzięki respektowanemu w tamtym czasie i kręgu kulturowym ,sądowi bożemu", a ponadto dostarczać informacji o związkach Dytryka z Pomorzem, które jako spadek po Mieszku I faktycznie stanowić mogło jego dzielnicę — lub jej część - przyznaną przez cesarza Konrada II na zjeździe w Merseburgu. W przeciwieństwie do przyjętej powszechnie hipotezy, zakładającej także utożsamienie anonimowego krewnego św. Stefana, przebywającego w Czechach w 1042 roku, z którymś z wygnanych książąt, moja propozycja ma tę przewagę, że nie wymaga bezzasadnej, częściowej korekty węgierskich źródeł. Zawarte $w$ nich podstawowe informacje nie stoją w żadnej sprzeczności ze stanem wiedzy o końcu panowania Mieszka II.

\section{Bibliografia}

\section{Źródla drukowane}

Annales Hildesheimenses. Ed. G. WAITZ. In: Scriptores Rerum Germanicarum in usum scholarum. Hannover 1878.

Chronici Hungarici compositio saeculi XIV. Ed. A. DomanovsZKY. In: Scriptores Rerum Hungaricarum. Vol. 1. Budapest 1937.

Galli Anonymi Cronicae et gesta ducum sive principum Polonorum. Ed. K. MALECZyŃsKi. W: Monumenta Poloniae Historica. Nova series. T. 2. Kraków 1952.

Powieść minionych lat. Tłum. i oprac. F. Sielicki. Wodzisław Śląski 2014.

Simonis de Keza Gesta Hungarorum. Ed. A. DomanovszKy. In: Scriptores Rerum Hungaricarum. Vol. 1. Budapest 1937.

Wiponis opera. Ed. H. BresslaU. In: Scriptores Rerum Germanicarum in usum scholarum. Hannover-Leipzig 1915.

Żywot św. Stefana króla Węgier czyli Kronika węgiersko-polska. Tłum. i oprac. R. GRzESIK. Warszawa 2003. 


\section{Opracowania}

Bagi D.: Królowie węgierscy w Kronice Galla Anonima. Kraków 2008.

BAGI D.: „Quamvis sim nobilior quam paganus ille, tamen pugnabo pro regni vestri commodo et honore domini ducis." Zur Kritik eines Kapitels der Ungarischen Chronikkomposition. W: Historia Narrat. Studia mediewistyczne ofiarowane Profesorowi Jackowi Banaszkiewiczowi. Red. A. PleszCZyńsKi. Lublin 2012.

Balzer O.: Genealogia Piastów. Kraków 1895.

Bieniak J.: Państwo Miecława. Studium analityczne. Warszawa 2012.

BorawsKa D.: Kryzys monarchii wczesnopiastowskiej w latach trzydziestych XI wieku. Warszawa 2013.

Dowiat J.: Bela I węgierski w Polsce (1031/32 - 1048). „Przegląd Historyczny” 1965, T. 56.

DróżDż K.: Kazimierz Odnowiciel. Polska w okresie upadku i odbudowy. Wodzisław Śląski 2009.

Duby G.: Damy XII wieku. Tłum. A. i K. CholŃscy. Warszawa 2000.

Font M.: I. András és Bölcs Jaroszlav. „Világtörténet” 2015, 4 (37).

GRZESIK R.: Kronika węgiersko-polska. Z dziejów polsko-węgierskich kontaktów kulturalnych w średniowieczu. Poznań 1999.

Grzesik R.: Polska Piastów i Węry Arpadów we wzajemnej opinii (do 1320 roku). Warszawa 2003.

GyöRfFy Gy.: A „lovagszent” uralkodása (1077-1095). „Történelmi Szemle” 1977, 3-4 (20).

Hóman B.: A szent László-kori Gesta Ungarorum és XII-XIII. századi leszármazói. Budapest 1925.

JASIŃSKI K.: Rodowód pierwszych Piastów. Warszawa-Wrocław [1992].

Kętrzyński S.: Kazimierz Odnowiciel 1034-1058. W: S. Kętrzyński: Polska X-XI wieku. Warszawa 1961.

Klaniczay G.: A Szent László-kultusz kialakulása. In: G. Klaniczay, L. Koszt, T. KöRmenDI: Nagyvárad és Bihar a korai középkorban. Tanulmányok Biharország történetéröl. Nagyvárad 2014.

Kovács Sz.: A kunok története a mongol hóditásig. Szeged 2012.

KRISTó Gy.: A magyarok és lengyelek kapcsolatai a 10.-12. században. „Történelmi Szemle” 2000, 1-2 (42).

KRISTó Gy.: A történeti irodalom Magyarországon a kezdetektöl 1241-ig. Budapest 1994.

Kristó Gy., MaKk F.: Az Árpád-házi uralkodók. Budapest 1988.

Labuda G.: Mieszko II król Polski (1025-1034). Czasy przełomu w dziejach państwa polskiego. Poznań 2008.

LABUdA G.: Udziat książat węgierskich $w$ walkach polsko-pomorskich za Mieszka II czy za Kazimierza Odnowiciela? W: Opuscula minora in memoriam Josepho Spors. Red. J. HaUZIŃSKI. Słupsk 1993.

MaKк F.: I. Béla. In: Korai magyar történeti lexikon (9-14. század). Szerk. Gy. Kristó, P. ENGEL, F. MAKK. Budapest 1994.

Mакк F.: Lampert. In: Korai magyar történeti lexikon (9-14. század). Szerk. Gy. Kristó, P. ENGEL, F. MAKK. Budapest 1994.

Medgyesy S.N.: Szent László király alakja a magyarországi barokk irodalomban. In: Szent király, lovagkirály. A Szent László-herma és a koponyaereklye vizsgálatai. Szerk. L.A. Kristóf, Z. Lukácsi, L. Patonay. Györ 2017.

OsıŃsKi J.: Z dziejów Polski wczesnopiastowskiej. Genealogia, ustrój, podbój. Kraków 2018. 
Piskorski J.M.: Pomorze plemienne. Historia - archeologia - językoznawstwo. Wodzisław Śląski 2014.

Rymar E.: Rodowód ksiąząt pomorskich. T. 1. Szczecin 1995.

Sochacki J.: Wstęp. W: Wipon: Chwalebne czyny cesarza Konrada II. Tłum. E. MilkamanoWICZ. Kraków 2005.

Ślıwiński B.: Pomorze $w$ polityce i strukturze państwa wczesnopiastowskiego (X-XII w.). „Kwartalnik Historyczny” 2000, T. 2 (107).

TĘGOWski J.: $W$ sprawie okoliczności $i$ datacji matżeństwa nieznanej z imienia Piastówny $z$ księciem węgierskim Béla. W: Res gestae Meridionales et Orientales. Studia ad Memoriam Professoris Henrici Ruciński. Red. E. BaGiŃsKa. Białystok 2009.

Wertner M.: Az Árpádok családi története. Nagy-Becskerek 1892.

Wiszewski P.: Domus Bolezlai. W poszukiwaniu tradycji dynastycznej Piastów (do około 1138 roku). Wrocław 2008.

Плетнёва С.А.: Половиъь. Москва 1990.

Темушев С.: География и динамика половеиких набегов на Русь (вторая половина XIначало XIII века). In: Rus' and the World of the Nomads (the Second Half of the $9^{\text {th }}-16^{\text {th }} \mathrm{c}$.). Publication from the $7^{\text {th }}$ International Scientific Conference, Plzeñ, $23^{\text {th }}-26^{\text {th }}$ November 2016. Ed. V. Nagirnyy. Krakow 2017 (Colloquia Russica, Series I, Vol. 7).

Karolina Madeja

\author{
Who Was the Duke of "Pomerania" \\ Defeated by the Hungarian Prince Béla?
}

Summary

Hungarian chronicles contain accounts regarding a duel between a Duke of Pomerania and the Hungarian Prince Béla, who, alongside his brothers, was at the time a guest of the Polish King Mieszko II. Polish historiography questions the identity of the Polish ruler, situating the events during the reign of Casimir I the Restorer, while Hungarian historiography doubts the opponent's connections with Pomerania or even the very fact of the duel. Thus, the following article shows that, in the context of anachronistic political data included in the Hungarian sources, the Pomeranian ancestry of the defeated duke is not sufficiently substantiated and cannot be the basis of a chronological correction. On the other hand, when it comes to the identity of the Polish ruler, a careful analysis of both the relationship between the Piast and the Arpad dynasty, as well as the last years of the rule of Mieszko II substantiates the hypothesis that it was indeed him who took in the exiled princes. The information included in the Hungarian chronicles possibly describes the situation after the Congress of Merseburg (1032): the dethroning of Theoderick, which could occur as a result of a trial by combat, practiced at that time in this cultural sphere. Moreover, if one were to treat the mention of the Duke of Pomerania as credible, it could be regarded as clue regarding Theoderick's province, which presumably could be Pomerania.

Key words: Mieszko II Lambert, the Piast monarchy crisis, Béla I, Polish-Hungarian relations, Pomerania 


\section{Karolina Madeja}

\section{Wer war der Herzog von „Pommern“, den der ungarische Herzog Béla besiegt hat?}

\section{Zusammenfassung}

Die ungarischen Chroniken informieren über ein Duell des Herzogs von Pommern mit dem Herzog Béla, der mit seinen Brüdern in Polen von Mieszko (II.) empfangen wurde. Die polnische Geschichtsschreibung stellt die Identität des Piastenherrschers in Frage, dadurch dass die Ereignisse auf die Herrschaft von Kasimir dem Erneuerer verschoben werden, die ungarische Geschichtsschreibung hinterfragt dagegen die Beziehung des Gegners zu Pommern und sogar die Tatsache, dass es zu einem Duell gekommen ist. Im Artikel wird aufgezeigt, dass die Informationen über die pommersche Herkunft des besiegten Herzogs im Zusammenhang mit den anachronistischen politischen Realien, die in den ungarischen Quellen gespeichert sind, unzureichend motiviert sind, deshalb können sie nicht als Grundlage für die chronologische Korrektur dienen. Was die Identität des polnischen Herrschers anbetrifft, so beweist die Analyse der Familienbeziehungen der Piasten und Arpaden sowie der letzten Jahre der Herrschaft von Mieszko II., dass gerade er die verbannten Fürsten aufgenommen hat. Die Überlieferung der ungarischen Chroniken kann die Situation nach dem Kongress in Merseburg (1032) beleuchten: Dietrichs Absetzung, zu der es infolge eines Duells, „Gottesurteils“ kommen konnte, das im damaligen Kulturkreis üblich war. Mehr noch: Wenn die Information über den Herzog von Pommern als glaubhaft erkannt wird, sollte sie nur als Indiz für den Dietrich zugehörigen Bezirk betrachtet werden, der Pommern sein konnte.

Schlüsselwörter: Mieszko II. Lambert, Krise der Piastenmonarchie, Béla I., polnischungarische Beziehungen, Pommern 